\title{
Evaluasi Program Jakarta Green And Clean Sebagai Implementasi CSR PT. Unilever Indonesia Tbk
}

\section{Evaluation Of Implementation Program Jakarta Green And Clean as a CSR Unilever Indonesia Tbk}

\author{
Mohamad Fahmi Hendrawan ${ }^{1}$, Ninuk Purnaningsih ${ }^{2}$ \\ ${ }^{1}$ Departemen Sains Komunikasi dan Pengembangan Masyarakat FEMA IPB \\ ${ }^{2}$ Dosen Departemen Sains Komunikasi dan Pengembangan Masyarakat FEMA IPB
}

\begin{abstract}
The purpose of this research were to identify company policy and analiyze the implementation of Corporate Social Responsibility PT. Unilever Indonesia Tbk, and evaluation of input, process, ouput of the Jakarta Green and Clean Program along with factors which influence the effectiveness of program implementation at $R W 13$, Kelurahan Cipinang Melayu, East Jakarta. This research were looking for relationship between internal and external factors with program output such as behavioral change which involve knowledge, attitude and action change. Result shows that behavioral change which involve knowledge, attitude and action were high because impact the program. It means that Jakarta Green and Clean Program succeed in implementation and respondens were helped by this program.
\end{abstract}

Keyword: Evaluation, Corporate Social Responsibility, Jakarta Green and Clean

Abstrak

Tujuan dari penelitian ini adalah untuk mengidentifikasi kebijakan perusahaan dan menganalisis pelaksanaan CSR PT. Unilever Indonesia Tbk, dan evaluasi dari input, proses, output dari Program Jakarta Green and Clean serta faktor yang mempengaruhi efektivitas pelaksanaan program di RW 13, Kelurahan Cipinang Melayu, Jakarta Timur. Penelitian ini melihat hubungan antara faktor internal dan eksternal dengan output Program seperti perubahan perilaku yang melibatkan pengetahuan, sikap dan tindakan perubahan. Hasil menunjukkan bahwa perubahan perilaku yang melibatkan pengetahuan, sikap dan tindakan yang tinggi karena dampak program. Ini berarti bahwa Program Jakarta Green and Clean berhasil dalam pelaksanaannya dibantu oleh responden.

Kata kunci: Evaluasi, Tanggung jawab sosial perusahaan (CSR), Jakarta Green dan Clean

\section{Pendahuluan}

Paradigma pembangunan di Indonesia telah mengalami perubahan. Diawali dari pembangunan berbasis ekonomi menjadi paradigma pembangunan berkelanjutan. Gagasan paradigma pembangunan berkelanjutan merupakan gagasan yang berupaya untuk memenuhi kebutuhan masa kini, tanpa mengurangi kebutuhan generasi masa depan. Berpijak dari konsep pembangunan berkelanjutan tersebut, terdapat 3 elemen keberlanjutan yang mendukung masing-masing stakeholders (perusahaan, pemerintah dan masyarakat) yaitu 1) keberlanjutan ekonomi,
2) keberlanjutan sosial, dan 3) keberlanjutan lingkungan. Dalam menghadapi persaingan bisnis dan perubahan paradigma pembangunan, maka perusahaan harus memiliki strategi untuk keberlangsungan bisnisnya. Salah satu strategi tersebut dikonsep dalam bentuk tanggung jawab sosial perusahaan. Tanggung jawab sosial perusahaan atau lebih dikenal dengan istilah Corporate Social Responsibility (CSR) merupakan bentuk pengembangan dari konsep kedermawanan sosial. Sebagai sebuah konsep yang semakin popular, Corporate Social Responsibility ternyata 
belum memiliki definisi yang tunggal. The Word Business Council for Sustainable Development (WBCSD) dalam publikasinya mendefinisikan bahwa Corporate Social Responsibility merupakan komitmen dunia usaha untuk terus menerus bertindak secara etis, beroperasi secara legal dan berkontribusi untuk peningkatan ekonomi, bersamaan dengan peningkatan kualitas hidup dari karyawan dan keluarganya sekaligus juga peningkatan kualitas komunitas lokal dan masyarakat secara lebih luas. Sementara Europan Commision mengemukakan: "Corporate Social Responsibility is a concept whereby companies integrate sosial and environmental concerns in their business operations and in their interaction with their Stakeholderss on a voluntary basis"

Dari dua definisi konsep di atas, dapat diketahui bahwa Corporate Social Responsibility belum memiliki suatu kesepakatan mengenai definisi bakunya. Hal ini dapat dimaklumi, mengingat Corporate Social Responsibility adalah sebuah konsep yang berkembang dengan cepat, sehingga definisinya pun bisa berubah menyesuaikan dengan perkembangannya. Namun demikian, kendati tidak mempunyai definisi tunggal, konsep Corporate Social Responsibility menawarkan sebuah kesamaan, yaitu keseimbangan antara perhatian terhadap aspek ekonomis dan perhatian terhadap aspek sosial serta lingkungannya dalam rangka mencapai pembangunan berkelanjutan. Motif perusahaan dalam melakukan program Corporate Social Responsibility beragam. Motif tersebut biasanya bersifat pemberian program dalam bentuk charity (amal atau derma), image building (promosi), tax-facility (fasilitas pajak), security prosperity (keamanan dan peningkatan kesejahteraan), atau bahkan money laundering (Achda dalam Febriana, 2008). Hal ini terlihat dari survey yang dilakukan Saidi (2003) bahwa 226 perusahaan di 10 kota Di Indonesia, ditemukan masih bermuatan promosi dan kepentingan bisnis pada kegiatan sumbangan sosial. PT. Unilever Indonesia Tbk merupakan salah satu perusahaan yang menyediakan berbagai kebutuhan konsumen memberikan perhatian lebih terhadap program Corporate Social Responsibility. Sebagai bentuk implementasi Corporate Social Responsibility, perusahaan melaksanakan salah satu program terkait dengan kepedulian terhadap lingkungan yaitu program Jakarta Green and Clean.

Program Jakarta Green and Clean merupakan bentuk replikasi program Green and Clean yang sebelumnya berhasil dilaksanakan untuk pertama kalinya Di Surabaya. Pelaksanaan program tersebut didasari oleh pemikiran perusahaan untuk menjadi bagian dari solusi permasalahan lingkungan khususnya masalah sampah. PT. Unilever Indonesia Tbk ingin menjadikan masyarakat sebagai pembentuk kekuatan dan agen peubah dalam mengatasi masalah sampah. Tujuan utama program pengelolaan sampah ini adalah untuk merubah pola perilaku masyarakat dalam pengelolaan lingkungan khususnya sampah secara mandiri di lingkungan sekitarnya. Program Jakarta Green and Clean akan terlaksana dengan efektif apabila terdapat keterkaitan antara input dan output program tersebut. Pola dan bentuk kebijakan merupakan input yang dimiliki perusahaan dalam pelaksanaan program CSR. Sementara karakteristik personal merupakan input yang dimiliki oleh masyarakat sebagai sasaran program. Dengan input yang memadai, output program pun secara efektif dapat tercapai. Dari pemikiran di atas, munculah rumusan permasalahan penelitian, yaitu: Bagaimana bentuk kebijakan dan wujud pelaksanaan Corporate Social Responsibility PT.Unilever Indonesia Tbk.? Serta Bagaimana input, proses, dan output program Jakarta Green and Clean serta faktor-faktor yang mempengaruhi efektivitas pelaksanaan program di RW 13 Kelurahan Cipinang Melayu Jakarta Timur?

\section{Metodologi Penelitian}

Penelitian ini menggunakan pendekatan kuantitatif yang didukung 
dengan pendekatan kualitatif. Pendekatan kuantitatif digunakan penulis untuk mencari informasi faktual secara mendetail yang sedang menggejala dan mengidentifikasi masalah-masalah atau untuk mendapatkan justifikasi keadaan dan kegiatan-kegiatan yang sedang berjalan (Singarimbun 1989). Pendekatan yang digunakan adalah metode survai dengan menggunakan kuisioner dan wawancara terstruktur. Penelitian dilaksanakan di dua lokasi. yakni di kantor Unilever Indonesia Tbk, sebagai penyelenggara program dan di salah satu lokasi peserta Jakarta Green and Clean Kelurahan Cipinang Melayu Jakarta Timur yang merupakan pemenang ke 2 yaitu di RW 13.

Penelitian ini dilakukan pada bulan April sampai dengan Juli 2009. Dalam penelitian ini, informan adalah pihak manajemen PT.Unilever Indonesia Tbk Jakarta khususnya yang bertanggung jawab dalam melaksanakan kegiatan CSR dan berhubungan dengan kepentingan masyarakat, dalam hal ini pihak Yayasan Unilever Peduli. Serta pihak-pihak lain yang berkepentingan dalam hal ini pihak pemerintah kelurahan Cipinang Jakarta Timur, fasilitator dan kader lingkungan program serta perwakilan dari LSM Aksi Cepat Tanggap sebagai salah satu stakeholder program. Populasi dari penelitian ini adalah semua warga RW 13 yang otomatis mengikuti program Jakarta Green and Clean 2008 yaitu sebanyak 1332 jiwa. Responden yang diambil dalam penelitian ini adalah 40 orang, dengan pembagian proporsi dilakukan secara purposive antara proporsi laki-laki dan perempuan seimbang yaitu masing-masing 20 orang.

Data yang diperoleh dianalisis secara kuantitatif dan kualitatif. Data primer yang berhasil dikumpulkan secara kuantitatif terlebih dahulu diolah dan di tabulasikan. Data dianalisis dengan menggunakan uji korelasi Rank Spearman dan uji statistik non parametik Chi pada taraf nyata $(\alpha) 0,05$, kemudian dianalisis dan diinterpretasikan untuk melihat kasus yang terjadi. Pengolahan data masing-masing variabel akan di proses dengan menggunakan software SPSS 15.0 dan Microsoft Excel 2007. Analisa kualitatif dilakukan dengan cara mendeskripsikan dan menginterpretasikan fenomena yang ada di lapang.

\section{Hasil Dan Pembahasan}

\section{Gambaran Umum Program Jakarta Green and Clean}

\section{Profil Program}

Jakarta sebagai ibu kota yang merupakan kota metropolitan, disisi lain juga mencerminkan kehidupan masyarakat yang padat aktivitas serta memiliki berbagai permasalahan, mulai dari permasalahan kependudukan sampai dengan masalah transportasi dan lingkungan. Sampah merupakan konsekuensi dari adanya aktivitas masyarakat. Setiap aktivitas masyarakat pasti menghasilkan buangan atau sampah. Jumlah atau volume sampah sebanding dengan tingkat konsumsi kita terhadap barang/material yang kita gunakan seharihari. Demikian juga dengan jenis sampah, sangat tergantung dari jenis material yang kita konsumsi. Oleh karena itu, pengelolaan sampah dipengaruhi juga oleh gaya hidup masyarakat.

Peningkatan jumlah penduduk dan perubahan gaya hidup sangat berpengaruh pada volume sampah. Misalnya saja, kota Jakarta pada tahun 1985 menghasilkan sampah sejumlah 18.500 perhari dan pada tahun 2000 meningkat menjadi 25.700 per hari. Jika dihitung dalam setahun, maka volume sampah tahun 2000 mencapai 170 kali besar candi Borobudur (volume candi Borobudur = 55.000 ), (Bapedalda, 2000). Selain itu, kurangnya ruang hijau di kawasan pemukiman dan ruang-ruang publik menjadi permasalahan tersendiri yang membutuhkan perhatian secara mendalam dari semua lapisan masyarakat. Mengingat begitu besarnya dampak yang ditimbulkan oleh sampah dari lingkungan yang tidak sehat, maka diperlukan upaya-upaya strategis dan 
sinergis dari berbagai pihak yang concern dalam melakukan pelatihan dan pendampingan secara langsung kepada masyarakat. (Sumber: Buku Laporan Pelaksanaan Program PT.Unilever, 2008).

Tujuan Umum dari program adalah melakukan pengembangan masyarakat dengan cara pendampingan dan pelatihan. adapun tujuan khusus dari program adalah 1) Membangun kesadaran masyarakat dalam menjaga lingkungan terutama dalam pengelolaan sampah dengan cara pemisahan sampah organic dan non organic. 2) Meningkatkan penghijauan di sekitar area program (DKI Jakarta). 3) Memperbanyak daerah resapan air dengan pembuatan Lubang Resapan Biopori. Penerima Manfaat dari program JGC 2008 ini adalah: 1) Warga RW peserta JGC. 2) Masyarakat DKI Jakarta pada umumnya. 3) Pemerintah dan dinas terkait. 4) Stakeholder program pada umumnya dan 5) Penerima manfaat langsung: sekitar 900000 jiwa (total penduduk dari 300 RW peserta JGC 2008)

Program dimulai sejak Juli 2008 dan berjalan selama 5 bulan hingga November 2008. Manfaat yang akan diterima dengan adanya program ini adalah: 1) Terciptanya lingkungan Jakarta yang lebih bersih dan hijau, 2) Tumbuhnya kesadaran masayrakat untuk mengelola sampah yang merupakan masalah lingkungan yang cukup besar di DKI Jakarta 3) Terbentuknya paguyubanpaguyuban lingkungan yang merupakan wadah berkumpulnya fasilitator JGC 2008, 4) Terjaganya motivasi dan semangat para fasilitator untuk terus menerus bekerja dengan ikhlas dalam menghijaukan dan memelihara kebersihan di lingkungan mereka. Stakeholders yang terkait dalam program: PT.Unilever Indonesia Tbk, Badan Pengelolaan Lingkungan Hidup Daerah (BPLHD), Radio Delta FM, Republika, dan LSM Aksi Cepat Tanggap (ACT).

Kebijakan Perusahaan tentang Corporate Social Responsibility (CSR) Perusahaan memandang bahwa pelaksanaan Corporate Social Responsibility merupakan investasi demi pertumbuhan dan keberlanjutan. Dalam menjalankan bisnis, perusahaan menyadari bahwa tanggung jawabnya bukan hanya mencari profit dan meningkatkan reputasi semata, melainkan tanggung jawab terhadap sosial dan lingkungannya. Melalui motto "Doing good is good for business" perusahaan memandang bahwa CSR merupakan hal yang tidak terpisahkan dalam pelaksanaan bisnis. Setiap aspek bisnis dilakukan dengan penuh tanggung jawab sehingga menciptakan dampak positif bagi masyarakat. Bentuk kebijakan CSR yang di lakukan perusahaan diwujudkan dengan mendirikan Yayasan Unilever Indonesia Peduli yang didirikan pada tahun 2000. Yayasan ini didirikan untuk meneruskan pemusatan sumber daya inisiatif yang akan memenuhi komitmen CSR perusahaan. Dalam meningkatkan reputasi, perusahaan menekankan pentingnya berkesinambungan dalam pelestarian lingkungan, kehidupan sosial, maupun pertumbuhan usaha. Dalam mengembangkan programnya, yayasan berpegang pada 4 strategi utama yaitu:

1. Relevansi; mengembangkan program yang terkait usaha.

2. Model; merumuskan model kegiatan atau program percontohan yang dapat diterapkan di daerah lain;

3. Kemitraan; bekerja sama dengan unsur-unsur masyarakat seperti LSM, lembaga pemerintah, pranata pendidikan pelaku bisnis lain dan

4. Replikasi; membuat replikasi model di daerah-daerah lain.

Perusahaan memandang bahwa pelaksanaan CSR tidak hanya dikhususkan untuk masyarakat secara luas (eksternal), melainkan menitikberatkan juga kepada karyawan dan para stakeholders yang terlibat dalam perusahaan. Perusahaan sudah mulai menerapkan konsep tanggung jawab sosialnya sejak perusahaan tersebut berdiri, jadi murni berasal dari dalam perusahaan tidak berdasarkan paksaaan atau tekanan. Adanya undang-undang yang mengatur yaitu UU No.40 Pasal 74 tahun 2007, tidak mempengaruhi perusahaan dalam kebijakan CSR, karena hal tersebut sudah diwujudkan sejak perusahan berdiri. Hanya saja 
perusahaan menganggap undang-undang tersebut sebagai suatu aturan untuk memperjelas program saja.

\section{Pelaksanaan CSR PT.Unilever Indonesia Tbk.}

Berpijak pada strategi dan pandangan yang ditetapkan mengenai CSR, perusahaan berupaya membawa perubahan bagi mitra dalam rantai nilai dan lingkup stakeholder yang paling luas. Untuk melihat sesuatu tidak hanya dari kacamata bisnis, tetapi juga melalui kacamata sosial.Pelaksanaan CSR PT.Unilever Indonesia dinaungi oleh Yayasan Unilever Peduli, yang berada di bawah direktur Human Resources and Corporate Relations. Misi dari Yayasan Unilever Indonesia Peduli adalah menggali dan memberdayakan potensi masyarakat, memberikan nilai tambah bagi masyarakat, memadukan kekuatan para mitra dan menjadi katalisator bagi pembentukan kemitraan. Dalam pelaksanaannya, Yayasan Unilever Peduli memfokuskan pada program-program yang sesuai dengan visi dan misi serta prinsip bisnis perusahaan. Serta program tersebut selalu melibatkan dan bertujuan pada masyarakat (Community Engagement). Adapun Program-program yang dilaksanakan adalah

\section{Program Lingkungan (Environment Program)}

2. Pengembangan Usaha Kecil Menengah melalui program Pemberdayaan Petani Kedele Hitam.

3. Program Kesehatan

4. Program Bantuan Kemanusiaan (Humanitarian Aid Program)

\section{Evaluasi Program Jakarta Green and Clean}

Program Jakarta Green and Clean merupakan salah satu program unggulan yang dilaksanakan PT.Unilever Indonesia Tbk. Program tersebut merupakan bentuk kepedulian perusahaan terhadap lingkungan dan keprihatinan perusahaan terhadap sampah yang ada sekarang. Selain itu, perusahaan menyadari akan sampah yang ditimbulkan dari produk yang dihasilkan perusahaan. Program Jakarta Green and Clean, menerapkan unsur pemberdayaan dalam konsep dan pelaksanaanya. Bentuk pemberdayaan dapat dianalisis dari proses pelaksanaan dan tujuan program tersebut.

Program Jakarta Green and Clean bertujuan untuk merubah perilaku masyarakat dengan memberikan pelatihan dan pertukaran informasi yang diberikan mengenai pengelolaan sampah sehingga nantinya masyarakat akan merubah pola perilakunya dalam pengelolaan sampah yang tentunya bermanfaat bagi masyarakat. Selain itu, dalam bidang ekonomi, masyarakat memiliki penambahan pendapatan. Pendapatan tersebut berasal dari aktivitas masyarakat dalam mengelola sampah kering menjadi bentuk kerajinan seperti tas, dompet, payung dan lain lain yang terbuat dari sampah plastik dan itu akan menambah pendapatan bagi masyarakat khususnya para ibu rumah tangga. Input dalam program dilihat dari input perusahaan sebagai penyelenggara dan input masyarakat sebagai sasaran program. Input perusahaan dilihat dari kebijakan yang terdapat dalam perusahaan yang dilihat dari bentuk dan konsep strategi CSR. Kebijakan perusahaan mempunyai pengaruh dalam program Jakarta Green and Clean, program tersebut dikatakan berhasil apabila dikonsep dengan baik oleh perusahaan dan terinternalisasi dalam wujud pelaksanaan CSR perusahaan. Input yang terdapat dalam perusahaan yaitu dilihat dengan adanya rancangan program mengenai Jakarta Green and Clean, serta melibatkan stakeholders yang terkait dengan adanya program, dan tentunya dana. Perusahaan pun menyediakan beberapa peralatan kebersihan dan juga mesin jahit untuk membantu keberlangsungan program.

Faktor Internal Faktor internal dalam penelitian ini adalah karakteristik responden yang merupakan ciri-ciri pribadi individu peserta program Jakarta Green and Clean di lokasi penelitian. Responden berjumlah 40 orang yang diambil secara acak terdiri dari 20 orang laki-laki dan 20 orang perempuan. 
Pengambilan sampel yang rata dilakukan dengan sengaja untuk melihat perbandingan antara responden laki-laki dan perempuan dalam mengikuti program Jakarta Green and Clean. Karakteristik responden dapat dilihat dalam tabel yang berdasarkan enam kategori. Kategori-kategori tersebut adalah usia, jenis kelamin, tingkat pendidikan, status kependudukan, motivasi mengikuti program dan tingkat pengetahuan terhadap program.

Tabel 1: Jumlah dan Persentase Responden Peserta Program Jakarta Green and Clean berdasarkan faktor internal responden.

\begin{tabular}{|c|c|c|c|}
\hline Karakteristik Responden & Kategori & $\begin{array}{l}\text { Jumlah } \\
\text { (orang) }\end{array}$ & $\begin{array}{l}\text { Persentase } \\
(\%)\end{array}$ \\
\hline \multirow{3}{*}{ Usia } & Muda $(<20$ th $)$ & 2 & 5 \\
\hline & Dewasa (21 th - 30 th) & 4 & 10 \\
\hline & Tua $(>30$ th) & 34 & 85 \\
\hline \multirow[t]{2}{*}{ Jenis Kelamin } & Laki-laki & 20 & 50 \\
\hline & Perempuan & 20 & 50 \\
\hline \multirow[t]{3}{*}{ Tingkat pendidikan } & Rendah (SD) & 3 & 7,5 \\
\hline & Menengah (SMP-SMA) & 31 & 77,5 \\
\hline & Tinggi (D3/S1/S2) & 6 & 15 \\
\hline \multirow[t]{2}{*}{ Status Kependudukan } & Warga tetap & 26 & 65 \\
\hline & Warga sementara & 14 & 35 \\
\hline \multirow[t]{3}{*}{ Motivasi } & Memperbaiki lingkungan tempat tinggal & 18 & 45 \\
\hline & $\begin{array}{l}\text { Menambah pengetahuan dalam mengelola } \\
\text { lingkungan }\end{array}$ & 21 & 52,5 \\
\hline & Hanya ikut-ikutan warga yang lain & 1 & 2,5 \\
\hline Tingkat pengetahuan & Rendah & 6 & 15 \\
\hline terhadap program & Tinggi & 34 & 85 \\
\hline
\end{tabular}

Ket: $n=40$

Tabel 1 menyajikan data mengenai jumlah dan persentase responden menurut faktor internalnya. Jumlah reponden lebih banyak berada di usia tua yaitu sebesar 85 persen, sementara usia dewasa hanya 10 persen dan usia muda hanya 5 persen. Hal ini dikarenakan masyarakat yang sering berada di cipinang adalah masyarakat yang tingkat kesibukannya rendah atau tidak memiliki kesibukan di luar. Biasanya, para Ibu Rumah Tangga yang tidak mempunyai pekerjaan sampingnya. Seperti yang diungkapkan responden

$$
\text { "...warga disini mah }
$$

kebanyakan pada disibuk di luar, apalagi anak muda yang sekolah dan para pekerja, paling adanya malam sepulang kerja dan sekolah, itupun jarang berkumpul mas..ya jadi yang sering muncul ya ibu-ibu $R T$ yang ga ada kerjaan mas.. (ibu HKM)

Sebagian besar responden merupakan masyarakat yang memiliki waktu senggang. Jenis kelamin mempunyai porsi yang seimbang antara laki-laki dan perempuan yaitu masing-masing 50 persen, hal ini dilakukan secara sengaja oleh peneliti, dengan tujuan untuk membandingkan output yang akan dihasilkan antara responden lakilaki dan perempuan. Jumlah responden dengan tingkat pendidikan sedang (SMPSMA) lebih banyak yaitu sebesar 77,5 persen, sementara sisanya sebesar 15 persen responden tergolong berpendidikan tinggi dan 7,5 persen responden berpendidikan 
rendah. Dalam status kependudukan, sebagian besar responden merupakan penduduk tetap yaitu penduduk yang memiliki rumah tetap dan permanen di lokasi tersebut yaitu sebesar 65 persen, dan responden yang berstatus sebagai penduduk sementara artinya penduduk yang bukan penghuni permanen biasanya ditandai dengan menempati rumah kontrakan atau kos-kosan berjumlah 35 persen. Pada dasarnya tidak ada pembedaan dari aparat pemerintah mengenai status penduduk warga, selama warga tersebut melapor dan mempunyai izin yang jelas.

Mengenai keterkaitannya dengan program Jakarta Green and Clean, baik penduduk sementara maupun tetap samasama dilibatkan dan tidak ada pembedaan, hanya saja karena kesibukan dari tiap masing-masing individu masyarakat, maka yang ikut andil sebagian besar adalah penduduk tetap yang biasanya ibu-ibu rumah tangga yang tidak bekerja. Motivasi masyarakat dalam mengikuti program Jakarta Green and Clean ini sebanyak 52,5 persen adalah untuk menambah pengetahuan meraka dalam mengelola lingkungan, sementara 45 persen responden menjawab untuk memperbaiki lingkungan tempat tinggalnya. Hal ini dapat dikatakan bahwa motivasi masyarakat program ini adalah positif artinya mempunyai tujuan yang baik dan terarah. Hanya ada 2,5 persen responden yang hanya ikut-ikutan warga lain. Tingkat pengetahuan warga terhadap program dikelompokan ke dalam faktor internal responden karena tingkat pengetahuan merupakan bentuk kepekaan responden terhadap program yang dijalankan.

Untuk menguji tingkat pengetahuan tersebut, responden diberikan 10 pertanyaan terkait dengan program Jakarta Green and Clean, kemudian setelah diolah 85 persen responden memiliki tingkat pengetahuan tinggi terhadap program artinya mereka mengetahui seluk beluk program, tujuan, penyelenggara dan manfaatnya. Sementara itu, terdapat 15 persen dengan tingkat pengetahuan rendah terhadap program, hal itu disebabkan karena diantara mereka hanya mengetahui programnya saja tanpa mengetahui lebih dalam lagi mengenai jenis, tujuan dan manfaat program Jakarta Green and Clean.

\section{Faktor Eksternal}

Faktor eksternal adalah faktor-faktor yang terdapat di luar internal responden yang dapat mempengaruhi ouput dari program Jakarta Green and Clean. Faktor eksternal dalam penelitian ini adalah regulasi pemerintah, hadiah atau penghargaan yang di terima, manajamen program yang dimulai dari tahap sosialisasi, pelaksanaan sampai evaluasi program, serta partisipasi masyarakat dalam program Jakarta Green and Clean. Secara lebih jelas dapat dilihat pada tabel 2.

Tabel 2: Jumlah dan Persentase Penilaian Responden terhadap Faktor Eksternal Program

\begin{tabular}{llcc}
\hline \multicolumn{1}{c}{ Faktor Eksternal } & \multicolumn{1}{c}{ Kategori } & $\begin{array}{c}\text { Jumlah } \\
\text { (orang) }\end{array}$ & $\begin{array}{c}\text { Persentase } \\
(\mathbf{\%})\end{array}$ \\
\hline Regulasi pemerintah setempat & Baik & 10 & 25 \\
& Buruk & 30 & 75 \\
Penghargaan/hadiah yang diterima & Mempengaruhi & 22 & 55 \\
& Tidak mempengaruhi & 18 & 45 \\
Manajemen program CSR & Baik & 35 & 87,5 \\
& Buruk & 5 & 12,5 \\
Partisipasi masyarakat dalam program & Tinggi & 24 & 60 \\
& Rendah & 16 & 40 \\
\hline
\end{tabular}

Ket: $\mathrm{n}=40$ 
Tabel 2 menyajikan data menegnai jumlah dan persentase faktor eksternal yang dimiliki responden. Sebesar 75 persen responden menyatakan bahwa regulasi pemerintah setempat buruk, artinya pandangan mereka terhadap peraturan pemerintah setempat terkait dengan pengelolaan lingkungan tidak berpengaruh terhadap responden. Ada atau tidak ada aturan yang dibuat, amsyarakat akan tetap menjalankan program Jakarta Green and Clean. Dalam hal ini, pemerintah setempat adalah pihak kelurahan Cipinang Melayu Jakarta Timur. Hanya 25 persen responden yang menyatakan bahwa regulasi pemerintah setempat baik. Hal tersebut dikarenakan belum ada aturan yang jelas mengenai pengelolaan lingkungan, baik tertulis maupun tidak tertulis serta tidak ada sanksisanksi yang jelas yang diberikan pemerintah setempat terutama yang terkait dengan pelanggaran pengelolaan lingkungan.

Secara garis besar aturan pemerintah setempat tidak mempengaruhi masyarakat dalam mengikuti program Jakarta Green and Clean. Seperti yang dinyatakan oleh reponden Bp.Shb

“...Sebenernya mas aturan

disini saya juga ga tau ya, tapi

setau saya ga ada aturan yang

resmi di kelurahan cipinang..ya

orang lurahnya aja baru ganti kok,

gimana mau jelas aturannya,.."

(Bp.Shb)

Di lain pihak, responden yang memiliki pandangan baik mengenai regulasi pemerintah menyatakan:

“...Setahu saya ada si mas, aturan aturan itu, dimana kalo ga bersihin sampah itu sanksinya harus nanam pohon atau tanaman di depan rumahnya, dan saya pikir aturan itu baik ya karena mendidik juga, hanya emang jarang dilakukan masyarakat ya..." (Ibu WTN)

Setelah dikonfirmasi kepada pihak kelurahan mengenai aturan-aturan yang ditetapkan pihak kelurahan, ternyata aturan tersebut ada hanya saja belum dituliskan. Biasanya aturan tersebut disampaikan kepada tiap RW untuk disampaikan lansung kepada masyarakat seperti kewajiban untuk kerja bakti sebulan sekali. Adapun sanksi yang diterapkan pun baik dan bermanfaat, seperti kewajiban menanam tanaman bagi yang tidak ikut berpartisipasi. Hanya saja, aturan tersebut kurang disosialisasikan secara resmi oleh pihak kelurahan jadi, masyarakat kurang mengetahui aturan-aturan yang ada, sehingga jelaslah bahwa sebagian besar responden tidak terlalu mengetahui aturan pemerintah setempat.

Penghargaan atau hadiah yang akan diterima oleh masyarakat apabila memenangkan program Jakarta Green and Clean ini sebanyak 55 persen mempengaruhi masyarakat dalam mengikuti program, artinya masyarakat mengetahui hadiah yang akan diterima, serta merupakan salah satu faktor pendorong megikuti program tetapi bukan merupakan tujuan utama mengikuti program. Sebanyak 45 persen responden menyatakan hadiah atau penghargaan tersebut tidak mempengaruhi dalam mengikuti program, karena sebagian besar dari mereka pun tidak megetahui secara pasti hadiah yang akan diterima, dan ada atau tidak ada hadiah tersebut mereka akan ikut berpartisipasi dalam program Jakarta Green and Clean.

\section{Output Program Jakarta Green and Clean}

Output program merupakan perubahan perilaku responden setelah diadakannya program, yaitu perubahan tingkat pengetahuan, perubahan sikap dan perubahan tindakan responden. Perubahan tingkat pengetahuan dinilai dari jumlah skor sepuluh pernyataan mengenai pengetahuan tentang pengelolaan lingkungan. Perubahan sikap dan tindakan dinilai dari jumlah skor sepuluh pernyataan masing-masing untuk sikap dan tindakan dalam mengelola lingkungan sekitar dan mempraktekan materi yang telah diajarkan melalui Skala Likert dari skala 1 sampai dengan 4. Hasil perubahan tingkat pengetahuan, sikap dan tindakan masyarakat dapat dilihat pada Tabel 3 
Tabel 3: Jumlah dan Persentase Perubahan Perilaku Responden Sesudah Program.

\begin{tabular}{|c|c|c|c|}
\hline $\begin{array}{c}\text { Perubahan Perilaku Masyarakat Peserta } \\
\text { Program }\end{array}$ & Kategori & $\begin{array}{l}\text { Jumlah } \\
\text { (orang) }\end{array}$ & $\begin{array}{l}\text { Persentase } \\
(\%)\end{array}$ \\
\hline Pengetahuan masyarakat dalam pengelolaan & Tinggi & 32 & 80 \\
\hline lingkungan setempat & Rendah & 8 & 20 \\
\hline $\begin{array}{l}\text { Sikap masyarakat dalam pengelolaan lingkungan } \\
\text { setempat }\end{array}$ & Positif & 35 & 87,5 \\
\hline setempat & Negatif & 5 & 12,5 \\
\hline
\end{tabular}

Ket: $n=40$

Tabel 3 menyajikan data mengenai jumlah dan persentase perubahan perilaku responden setelah program selesai dilaksanakan. Tingkat pengetahuan responden terhadap pengelolaan sampah dapat dikatakan tinggi yaitu sebesar 80 persen, sementara 20 persen responden memiliki tengkat pengetahuan rendah terhadap program. Tingkat pengetahuan warga yang tinggi memang sebagian besar didapat setelah adanya program Jakarta Green and Clean tersebut. Sebelumnya, masyarakat tidak mengetahui secara mendetail mengenai pengelolaan lingkungan yang baik dan benar, tetapi setalah dilakukan pelatihan dan pembinaan mereka menjadi lebih terbuka dan memahami. Seperti yang dinyatakan beberapa responden berikut ini:

$$
\text { "...dulu si mas kalo }
$$

sampah saya suka dibakar kan

daripada menuh-menuhin,

tetapi setelah adanya program

saya jadi tau kalo sampah itu

ga boleh dibakar, apalagi

sekarang jadi gampang ya

setelah ada bank sampah, nuker

sampah tapi dapet uang juga..."

(Ibu Mnr)

Hal tersebut menggambarkan bahwa sebagian besar masyarakat tingkat pengetahuannya meningkat setelah adanya program Jakarta Green and Clean. Sementara untuk 20 persen yang memiliki pengetahuan rendah dikarenakan jarang berpartisipasi dalam beberapa kegiatan pelatihan yang diberikan. Sebanyak 87,5 persen responden memiliki sikap positif terhadap pengelolaan sampah setelah adanya program, hal ini menandakan bahwa program berhasil merubah sikap atau pandangan masyarakat terhadap pengolaan sampah. Setelah adanya program, masyarakat menjadi lebih peduli dan memperhatikan kondisi lingkungan sekitarnya untuk menjadi lebih baik dan bersih dibanding sebelum adanya program.

Berdasarkan Tabel 3, 55 persen responden memiliki tindakan yang aktif dalam mengelola lingkungan dimulai dari membuang sampah pada tempatnya, memanfaatkan bank sampah, menghadiri berbagai kegiatan lingkungan sampai tindakan menggunakan produk daur ulang sampah yang dibuat sendiri dan melaksanakan semua yang telah diajarkan dalam program Jakarta Green and Clean. Sementara, sisanya sebanyak 45 persen masih bersifat pasif artinya sebagian besar kurang melakukan apa yang telah diajarkan dalam program. Apabila dilihat secara keseluruhan tindakan masyarakat dalam mengelola sampah memang tidak memiliki persentase yang menonjol atau terlalu besar, artinya tindakan masyarakat memang perlu diperbaiki lagi, jadi tidak hanya pengetahuan saja yang cenderung tinggi, karena harus dilandasi dengan tindakan yang aktif juga terhadap pengelolaan lingkungan.

Hubungan antara Karakteristik Faktor Internal dengan Perubahan Perilaku Sesudah Program Jakarta Green and Clean Perubahan perilaku dalam penelitian ini mencakup perubahan tingkat pengetahuan, sikap dan tindakan peserta program. Hubungan antara perubahan tingkat pengetahuan, sikap dan tindakan setelah 
adanya program dengan faktor internal responden yang mencakup usia, jenis kelamin, tingkat pendidikan, status kependudukan, motivasi mengikuti program dan tingkat pengtahuan terhadap program dianalisis menggunakan tabulasi silang dan kemudian dilakukan uji statistik non parametik Chi Square. Uji-uji tersebut menggunakan skala nominal dan ordinal dalam bentuk angka dan frekuensi yang berupa data skor. Patokan pengambilan keputusan berdasarkan nilai Asymp Sig adalah jika nilai Asymp Sig (2-sided) lebih kecil dari $\alpha=(0,05)$, maka Ho ditolak, yang berarti bahwa terdapat perbedaan antara variabel-variabel yang diuji.

Tabel 4 Hasil analisis Chi Square antara Faktor Internal responden dengan Perubahan Tingkat Pengetahuan Sesudah Program.

\begin{tabular}{lll}
\hline \multicolumn{1}{c}{ Faktor Internal } & \multicolumn{1}{c}{$\boldsymbol{p \text { -value }}$} & \multicolumn{1}{c}{ Keterangan } \\
\hline Usia & 0,414 & Tidak Signifikan \\
Jenis kelamin & 0,002 & Signifikan \\
Tingkat pendidikan & 0,826 & Tidak Signifikan \\
Status kependudukan & 0,507 & Tidak Signifikan \\
Motivasi mengikuti program & 0,853 & Tidak Signifikan \\
Tingkat pengetahuan terhadap program & 0,376 & Tidak Signifikan \\
\hline
\end{tabular}

Ket: signifikan jika $p$-value < alpha $(0,05)$

Tabel 4 menyajikan data mengenai hasil analisis Chi Square antara faktor internal dengan tingkat pengetahuan. Secara keseluruhan dapat dikatakan bahwa variabelvariabel faktor internal tidak memiliki perbedaan dengan perubahan tingkat pengetahuan. Hanya jenis kelamin yang menunjukan adanya hubungan yang signifikan pada perubahan tingkat pengetahuan.Tabel 4 menyajikan data mengenai hasil analisis Chi Square antara faktor internal dengan tingkat pengetahuan. Secara keseluruhan dapat dikatakan bahwa variabel-variabel faktor internal tidak memiliki perbedaan dengan perubahan tingkat pengetahuan. Hanya jenis kelamin yang menunjukan adanya hubungan yang signifikan pada perubahan tingkat pengetahuan.

Hubungan Faktor Eksternal Responden dengan Perubahan Perilaku Sesudah Program Jakarta Green and Clean

Hubungan antara perubahan perilaku responden yang meliputi perubahan tingkat pengetahuan, sikap dan tindakan dengan faktor eksternal yang meliputi regulasi pemerintah setempat, penghargaan atau hadiah yang diterima, manajemen program, dan partisipasi masyarakat dalam program dianalisis dengan menggunakan uji korelasi Rank Spearman. Korelasi Rank Spearman menyatakan hubungan antara kedua variabel yang ordinal dan tidak memerlukan prasyarat data terdistribusi normal. Nilai korelasi ditunjukan dengan nilai koefisien korelasi Spearman. Hasil analisis korelasi Rank Spearman yang menunjukan hubungan antara keragaan pelatihan terhadap perubahan perilaku program dapat dilihat pada Tabel 5.

Tabel 5 menyajikan data mengenai hasil analisis Rank Spearman antara faktor eksternal dengan tingkat pengetahuan. Secara keseluruhan dapat dikatakan bahwa variabel-variabel faktor eksternal tidak memiliki perbedaan dengan perubahan tingkat pengetahuan. Hanya partisipasi masyarakat dalam program yang menunjukan hubungan yang signifikan pada perubahan tingkat pengetahuan. 
Tabel 5. Hasil Analisis Korelasi Rank Spearman antara Faktor Eksternal terhadap Tingkat Pengetahuan Responden Sesudah Program.

\begin{tabular}{llll}
\hline Faktor Eksternal & Koefisien Korelasi & p-value & Keterangan \\
\hline Regulasi Pemerintah Setempat & 0,289 & 0,071 & Tidak Signifikan \\
Penghargaan/hadiah yang diterima & 0,302 & 0,059 & Tidak Signifikan \\
Manajemen program & 0,189 & 0,243 & Tidak Signifikan \\
& & & \\
Partisipasi Masyarakat dalam Program & $0,612(* *)$ & 0,000 & Signifikan \\
\hline Ket: $\mathrm{n}=40$
\end{tabular}
Ket: $\mathrm{n}=40$

Berdasarkan hasil uji Korelasi Rank Spearman terdapat hubungan yang signifikan antara tingkat partisipasi responden dengan tingkat pengetahuan responden. Hal ini sesuai dengan kenyataan di lapangan bahwa responden yang aktif mengikuti program pasti megikuti detail dan alur program, serta mengikuti semua program yang ada, dan berpengaruh terhadap tingkat pengetahuannya, hal ini dapat dibandingkan dengan responden dengan tingkat partisipasi rendah. Jadi dapat disimpulkan, semakin tinggi tingkat partisipasi masyarakat maka semakin tinggi pula tingkat pengetahuan.

\section{Kesimpulan}

Persepsi mahasiswa Departemen Sains Komunikasi dan Pengembangan Masyarakat tahun masuk 2006 yang telah mengikuti Mata Kuliah Gender dan Pembangunan sebagian besar adalah tinggi. Sosialisasi primer yang memiliki hubungan signifikan dengan tingkat persepsi mahasiswa terhadap kesadaran gender hanya jenis kelamin. Sedangkan sosialisasi primer lainnya seperti agama, suku bangsa, tingkat pendidikan orang tua, jenis pekerjaan orang tua, dan tingkat penghasilan orang tua tidak memiliki hubungan secara signifikan dengan persepsi terhadap kesadaran gender. Begitu pula dengan sosialisasi sekunder yang dialami mahasiswa baik tempat tinggal, kegiatan organsisasi, interaksi dengan media massa, hubungan dengan teman, nilai mutu gender dan indeks prestasi kumulatif tidak memiliki hubungan yang signifikan dengan persepsi terhadap kesadaran gender.

\section{Daftar Pustaka}

Saidi Z. 2003. Sumbangan Sosial Perusahaan", Profil dan Pola Distribusinya di Indonesia : Survei 226 Perusahaan di 10 Kota oleh PIRAC. Jakarta(ID) : Ford Foundation

Sarwono J.2006. Metode Penelitian Kuantitatif dan Kualitatif. Yogyakarta(ID) : Graha Ilmu.

Singarimbun M dan Effendi S. 1989. Metode Penelitian Survey. Jakarta(ID): LP3ES

Yusuf. 2007. Membedah Konsep dan Aplikasi CSR (Corporate Social Responsibility. Gresik(ID) : Fascho Publishing.

Yusuf Tayibnapis, Farida. Evaluasi program dan instrument evaluasi. Jakarta(ID): PT.Rineka Cipta. 